\title{
Caros Amigos Associados
}

Chegou o momento mais aguardado por todos da família ABPol o $5^{\circ} \mathrm{CBPoL}$ e, como é do conhecimento de todos vocês, o fim do meu mandato como presidente. Foram 2 anos muito gratificantes para mim, não só pelas realizações como pelo carinho e reconhecimento que recebi de todos, tanto dos profissionais da área acadêmica como industrial.

Nesta última mensagem gostaria de sumarizar para vocês as principais realizações desta Diretoria:

1) Realizamos 15 treinamentos com instrutores locais, beneficiando mais de 300 profissionais, e 3 internacionais em parceria com a SPE - Society of Plastic Engineers - com a presença de 100 profissionais voltados, principalmente, à indústria de transformação, como foram os cursos de Termoformagem Industrial -Tecnologia para o futuro; Termofixos Modernos: Desenvolvimentos, Aplicações e Máquinas de Transformação; Tecnologia de injeção e extrusão; Polímeros para Embalagens, entre outros.

2) A comemoração dos 10 anos de ABPol, em setembro/98, contou com o prestígio de importantes líderes de opinião do setor de Polímeros, transformando-se num dos principais eventos de 98.

3) Os $2^{\circ}$ e $3^{\circ}$ Seminários das Comissões Técnicas, realizados em maio/98 e maio/99, respecti- vamente, foram um verdadeiro sucesso, reunindo em média 100 participantes, principalmente do setor industrial.

4) As 3 comissões técnicas continuam a todo vapor com média de 20 participantes por reunião.

5) Consolidamos e fortalecemos as regionais do Rio de Janeiro e do Sul.

6) Recebemos o apoio de novos sócios patrocinadores e coletivos, fortalecendo ainda mais a representatividade da ABPol perante o setor industrial.

7) $\mathrm{E}$, finalmente, o $5^{\circ} \mathrm{CBPoL}$ que tem como principal objetivo prestigiar os pesquisadores nacionais. Neste ano, mais de 480 trabalhos serão apresentados, o que por si só já garante o sucesso deste, que já é considerado o melhor evento científico/tecnológico do Brasil.

Todas estas realizações não teriam sido possíveis sem o empenho e dedicação dos membros da Diretoria, Conselho e Patrocinadores. A todos muito obrigado. Tenho certeza que todos vocês sentem-se orgulhosos, como eu, por mais esta conquista e contribuição para a área de Polímeros do Brasil.

E a todos os Associados muito obrigado pelo apoio que recebi nos momentos mais difíceis. Desejo a todos um ótimo Congresso e que continuem prestigiando e valorizando a nossa ABPol.

Até Breve.

Edson R. Simielli Presidente 